\begin{tabular}{|l|l|l|l|l|}
\hline Cuadernos de Investigación Geográfica & 2002 & $\mathbf{N}^{\circ} 28$ & pp. 109-126 & ISSN 0211-6820 \\
\hline
\end{tabular}

(C) Universidad de La Rioja

\title{
INTEGRATED CATCHMENT MANAGEMENT: THE MOOI RIVER (NORTHWEST PROVINCE, SOUTH AFRICA) AS A CASE STUDY
}

\author{
I.J. VAN DER WALT ${ }^{(1)}$ \\ F. WINDE ${ }^{(2)}$ \\ B. NELL ${ }^{(3)}$
}

(1) Geography \& Environmental Studies, School of Environmental Sciences and Management, Potchefstroom University for Christian Higher Education, Potchefstroom 2520, South Africa. e-mail: GGFIJVDW@puknet.puk.ac.za

(2) University of Jena, Department of Geography, 07743 Jena, Germany.

(3) Potchefstroom City Council, Potchefstroom, 2520, South Africa.

ABSTRACT: The city of Potchefstroom is situated at the lower end of the Mooi River catchment. Since 1842 the Mooi River has been the sole water supply of Potchefstroom, which currently has about 210000 resi dents. The Mooi River is fed mainly by dolomitic eyes and springs. Since the 1930's, large-scale gold mining commenced to work the ore, which occur in the Witwatersrand sedimentary layer underlying the dolomites. To reduce the danger of flooding, some dolomitic compartments were dewatered by the gold mines, sometimes resulting in catastrophic environmental impacts. Furthermore, slimes dams ${ }^{l}$ were constructed on dolomitic areas resulting in the seepage of large volumes of polluted water into the underlying aquifer.

The indiscriminate mining practices, as well as the rapid development of informal and formal settlements, some diamond mining enterprises as well as agriculture in the central and upper reaches of the catchment, resulted in a steady increase in salt loads in the water of the Mooi River, as well as the deposition of high concentrations of trace metals, especially uranium, which is associated with the gold bearing ore. Recently, it was announced that some mines in the Mooi River Catchment have reached the end of their productive lives, and that projects to re-water the dolomitic compartments were underway.

This paper explores the possible environmental impacts associated with re-watering the dolomitic compartments, and indicates how a lack of integrated catchment planning and management are currently exacerbating the already manifested environmental impacts. Finally, an integrated approach to the rehabilitation and restoration of the catchment to a sus tainable water resource is suggested.

1 Waste from the gold reclaiming plants is slurried and pumped to huge tailings deposit dams. In South Africa, these dams are called «slimes dams». 
RESUMEN: La ciudad de Potchefstroom está situada en la parte infe rior de la cuenca del río Mooi. Desde 1842 el río Mooi ha sido la única fuente de abastecimiento de Potcheftstroom, que actualmente cuenta con unos 210000 habitantes. El río Mooi se alimenta de fuentes dolomíticas. Desde los años 30 se inició la extracción de oro en el nivel sedimentario situado por debajo de las dolomitas. Para reducir el peligro de inundación algunos compartimentos dolomíticos furon desecados por las empresas mineras, a veces con resultados ambientales catastróficos. Además se construyeron presas para el almacenamiento de lodos, favoreciendo la contaminación de acuíferos.

Las prácticas mineras indiscriminadas, así como el rápido desarrollo de asentamientos humanos, algunas empresas de diamantes y la actividad agrícola en la parte central y superior de la cuenca han dado lugar a un incremento en la carga de sal del río Mooi, y al depósito de elevadas concentraciones de metales pesados, especialmente uranio, que se asocia con los placeres auríferos. Recientemente se ha anunciado que algunas minas de la cuenca del río Mooi han finalizado su vida productiva y que existen proyectos para recargar de agua los compartimentos dolomíticos.

Este trabajo explora los posibles impactos ambientales relacionados con la recarga hídrica de los compartimentos dolomíticos, y demuestra que una ausencia de planificación integral de la cuenca están incrementando actualmente los impactos ambientales. Finalmente, se sugiere una aproximación integrada a la rehabilitación y restauración de la cuenca para la sostenibilidad de los recursos hídricos.

Key-words: Integrated catchment planning, Water resources, Mining, Water pollution, South Africa.

Palabras clave: Planificación integral de cuencas, Recursos hídricos, Minería, Contaminación, Sudáfrica.

\section{Introduction}

The Mooi River catchment is situated in the western Gauteng and NorthWest provinces of South Africa (Figure 1). The catchment has a total area of $1800 \mathrm{~km}^{2}$, but due to extensive dolomitic outcrops, only $44,2 \%$ of the catchment yield significant runoff. Precipitation on the rest of the catchment $\left(1004 \mathrm{~km}^{2}\right)$ ends up as groundwater recharge and feeds the Mooi River and its tributaries through several dolomitic eyes. The mean annual precipitation is $683 \mathrm{~mm}$ and the mean annual potential evaporation $1650 \mathrm{~mm}$. The Mooi River has three major sub-catchments, namely the Wonderfontein Spruit (northeastern reach), the Mooi River proper (northern reach), and the Loop Spruit (eastern reach). Four major dams are found in the Mooi River catchment, namely the Klerkskraal Dam, the Boskop Dam, the Klipdrift Dam and the Potchefstroom Dam (Figure 1).

Large-scale mining commenced in the Wonderfontein Spruit sub-catchment during the 1930's. The mining is concentrated in the Far West Rand (Krugersdorp) and Carletonville area, which comprises the upper and middle catchment of the Wonderfontein Spruit, as well as the upper reaches of the Loop Spruit. Some of the richest gold mines in the world are situated in this area and some $18000 \mathrm{t}$ gold has been pro- 


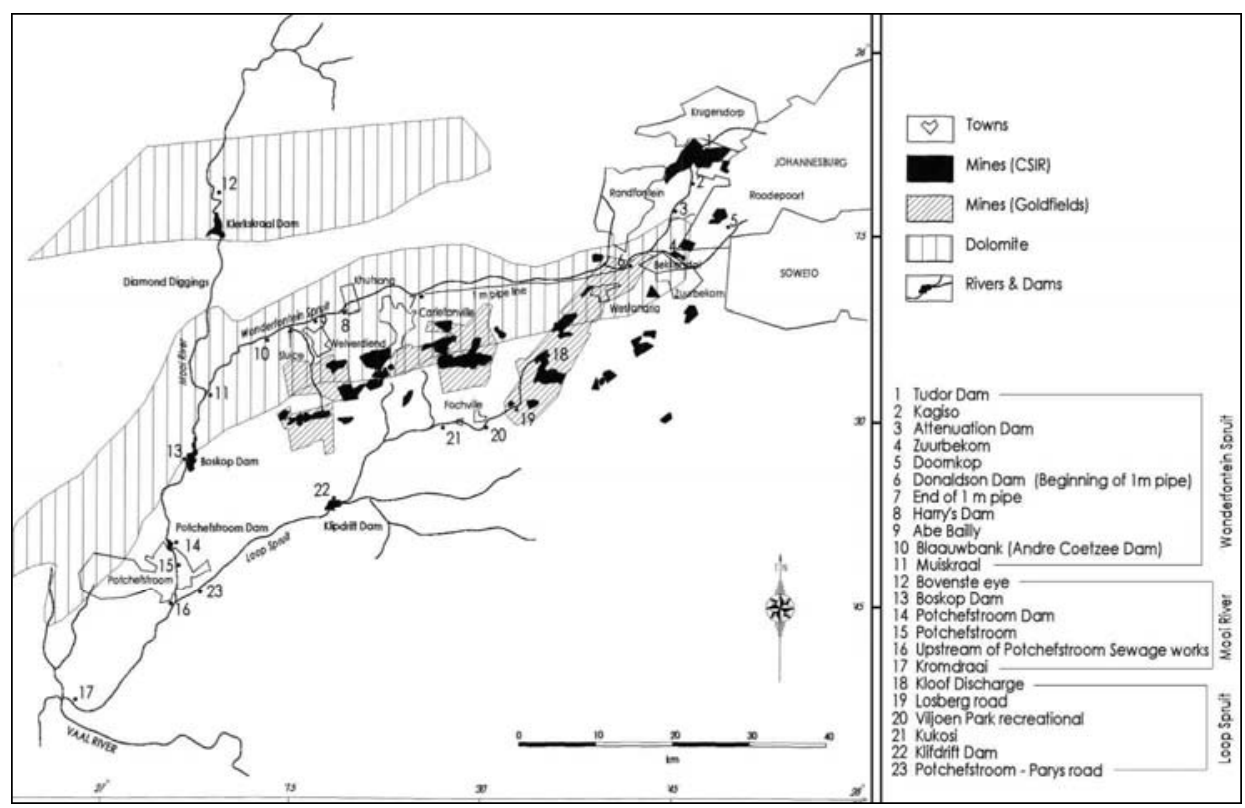

Figure 1

duced up to 1994 (Council for Geoscience, 1998). Water from these mines (effluent as well as storm water), as well as effluent from several urban and industrial areas and informal settlements drain towards the Wonderfontein Spruit. Diffuse water-borne as well as particle-bound pollution from slimes dams, rock dumps, sand heaps and informal settlements contribute to the contamination of the water environment.

The dolomitic underground (part of the Transvaal geological sequence) is divided into several compartments, separated by impermeable vertical syenite dykes which intruded during the Mokolian age (1300 Ma) (SACS, 1980). The gold-bearing Witwatersrand Supergroup underlies these dolomites. In order to mine for gold, several of these dolomitic compartments have been de-watered. While the compartments were being dewatered, a substantial increase in the runoff of the Wonderfontein Spruit were observed before a state of equilibrium between groundwater recharge and pumping volumes were reached (data from the Department of Water Affairs \& Forestry). In the middle part of the Wonderfontein Spruit, the stream has been diverted into a $1 \mathrm{~m}$-diameter pipe to prevent the water from draining back into the underground through sinkholes, which are abundant in the river channel.

In the lower Wonderfontein Spruit, farming and large scale mining are the predominant land uses. Downstream farmers have been adversely affected by the drawdown of the water table as well as the subsequint formation of sinkholes. The confluence of the Wonderfontein Spruit and the Mooi River is situated just upstream of the Boskop Dam (Figure 1). 
The predominant land-uses in the northern sub-catchment (Mooi River) are crop farming and grazing, although some small scale diamond diggings occur in the stream channel of the Mooi River between the Klerkskraal Dam and the Boskop Dam. These diggings are destroying the floodplain and riparian habitats and have resulted in silting of the Mooi River upstream of the Boskop dam with associated problems for farmers extracting water from the Mooi River for irrigation and stock watering. Between the Boskop Dam and Potchefstroom Dam, the Mooi River State Water Scheme has been established to provide water to about 4750 ha of irrigated land.

Land-uses in the eastern sub-catchment (Loop Spruit) are also mainly crop farming and grazing, although several goldmines, situated on the watershed between the Loop Spruit and the Wonderfontein Spruit sub-catchments, discharge water towards the Loop Spruit. The Loop Spruit joins the Mooi River just downstream of the city of Potchefstroom.

The city of Potchefstroom is situated between the Potchefstroom Dam and the confluence of the Mooi River and the Loop Spruit. This city has about 210000 inhabitants and the Mooi River has been the sole source of water since 1842. Except for a few downstream farmers, Potchefstroom is the final consumer of water from the Mooi River before it flows into the Vaal River about 30km downstream.

\section{Problem Statement}

Since the late 1950's and early 1960's, the surface water quality gradually deteriorated in the Boskop Dam as well as in the Potchefstroom Dam, as main reservoirs for the drinking water supply of Potchefstroom. High salt loads, especially sulphates, started to impact on the quality of water that Potchefstroom extracts for domestic purposes. From a back-

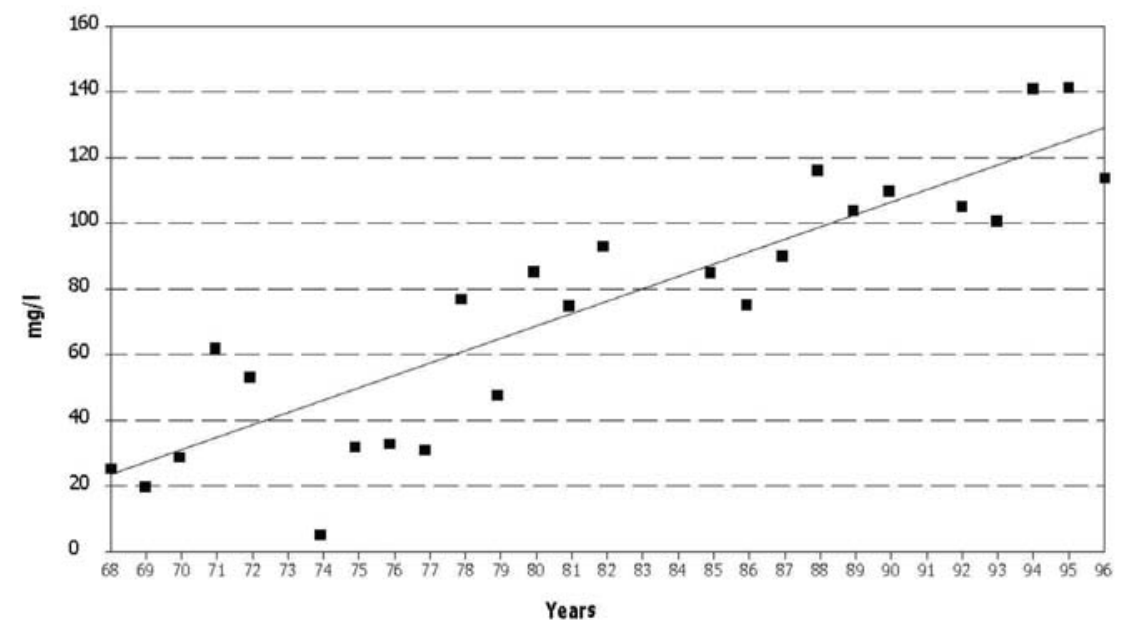

Figure 2 
ground level of $10 \mathrm{mg} . \mathrm{r}^{1}$, sulphate levels gradually increased to $160 \mathrm{mg} . \mathrm{l}^{-1}$ and even higher during dry seasons (Figure 2). The taste of water has been affected and many citizens of Potchefstroom buy bottled water or install purification units at their houses. In addition to this, the quality of water decanting through dolomitic eyes has also been significantly affected. In Figure 3, the increasing electrical conductivity and sulphate concentration over a 30 year period (1969 to 1996) of water from the Gerhardminnebron dolomitic eye in the Wonderfontein sub-catchment, is shown. Figure 4 shows similar trends in the Turffontein dolomitic eye, also situated in the Wonderfontein sub-catchment. Furthermore, there is an increasing suspicion of water contamination by heavy metals as well as radio-nuclides originating at the mining activities in the sub-catchment (DWAF, 1999).

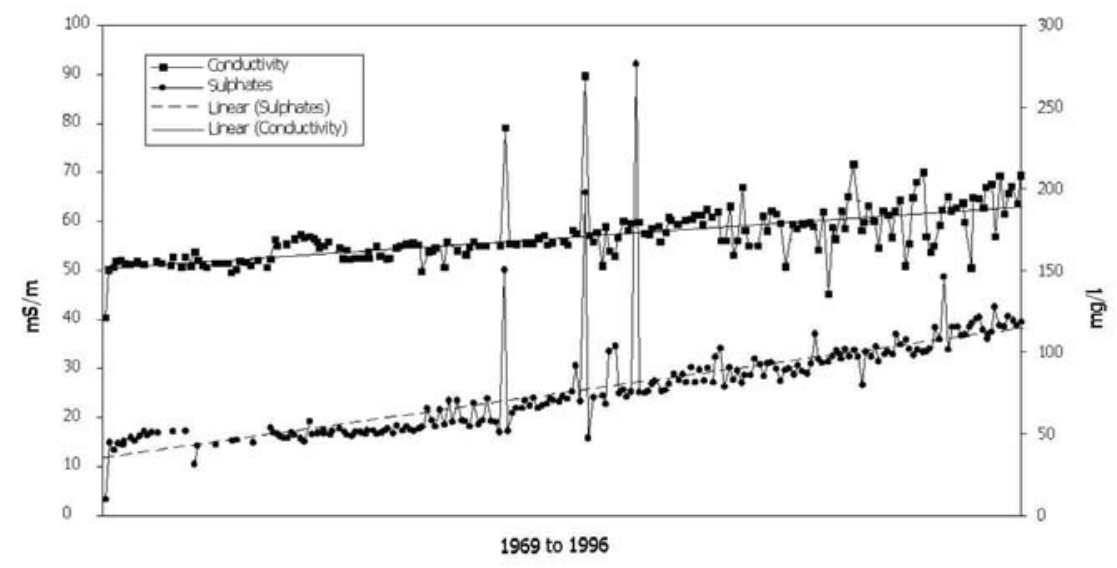

Figure 3

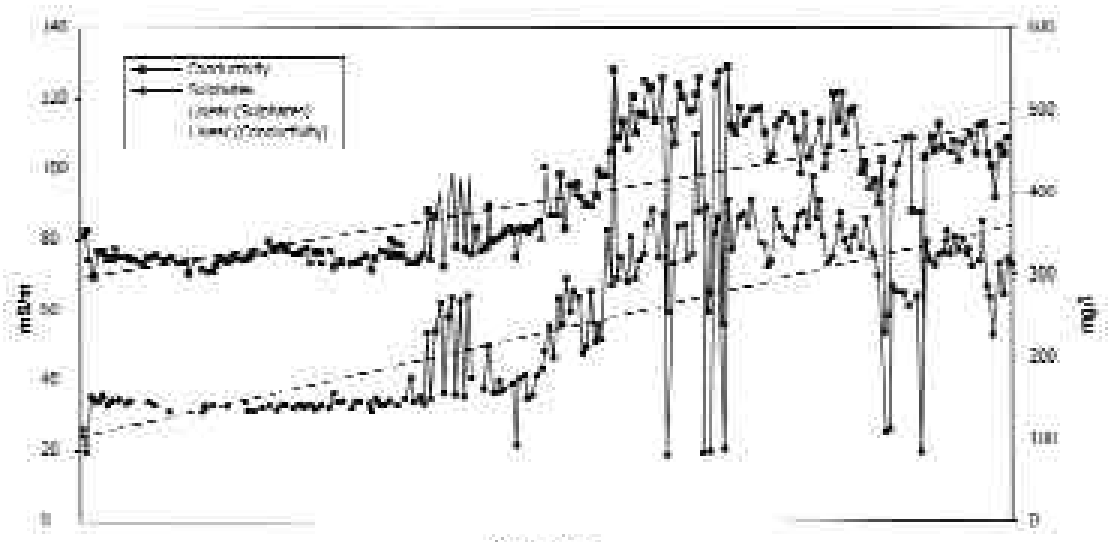

1969 1996

Figure 4 
The problem facing everyone within the catchment, and especially the downstream users (the city of Potchefstroom), is how this catchment should be managed to secure a sustainable, clean source of water for all. In the following sections, the impacts of the various land uses on the Mooi River Catchment will be explored in more detail, and possible management strategies will be discussed.

\subsection{Longitudinal water quality profile - Wonderfontein Spruit}

Concentrations of some of the contaminants in the Wonderfontein Spruit are shown in Figures 5 to 7.

The high concentrations of contaminants in the upper reaches of the Wonderfontein Spruit (Tudor Dam) is the result of leaching as well as erosion from older slimes dams near Krugersdorp on the West Rand. The high TDS values correlate well with sulphate concentrations (Figure 5), although one would expect high carbonate concentrations as well due to the dolomites. Contamination decreases towards the Attenuation Dam (see Figure 1), after which there is a gradual downstream increase in all contaminants.

From the above figures, it is clear that mining, industry as well as informal settlements impact severely on the water quality of the Wonderfontein Spruit. In addition to the high salt loads, mining also adds various trace metals to the Wonderfontein Spruit, of which uranium is of particular concern.

Most sampling sites in the catchment show low levels of water-borne radio-nuclides, but the sites that show significant concentrations are associated with the discharge of mine water into the Spruit (Wade et al., 2000). Radioactivity levels in the water column

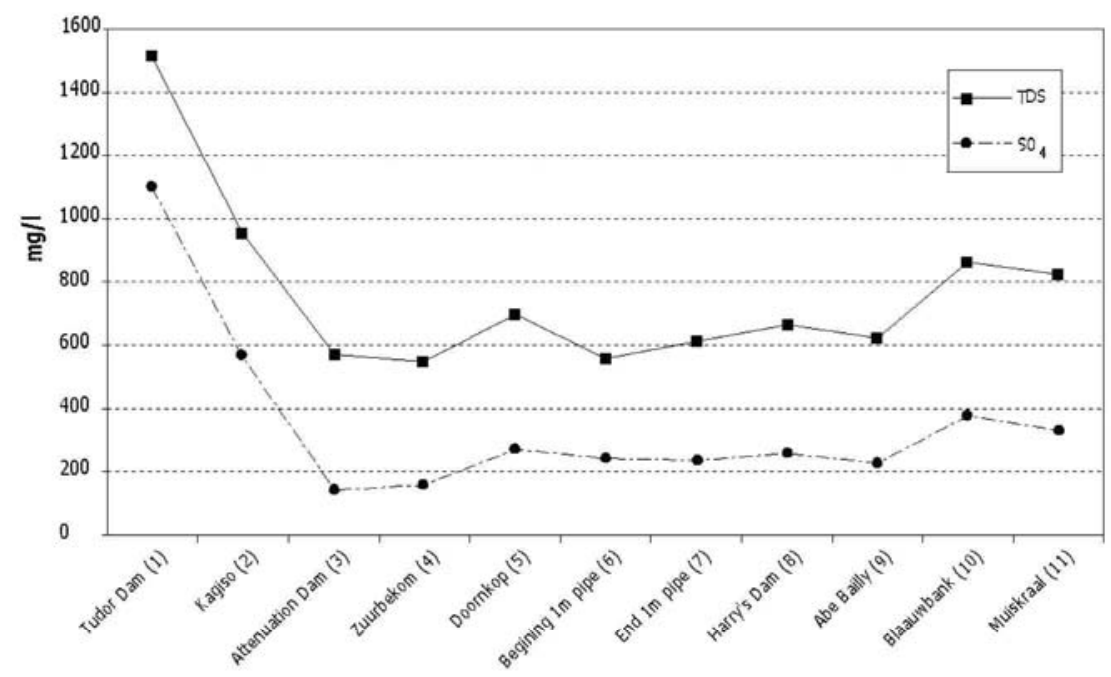

Figure 5 


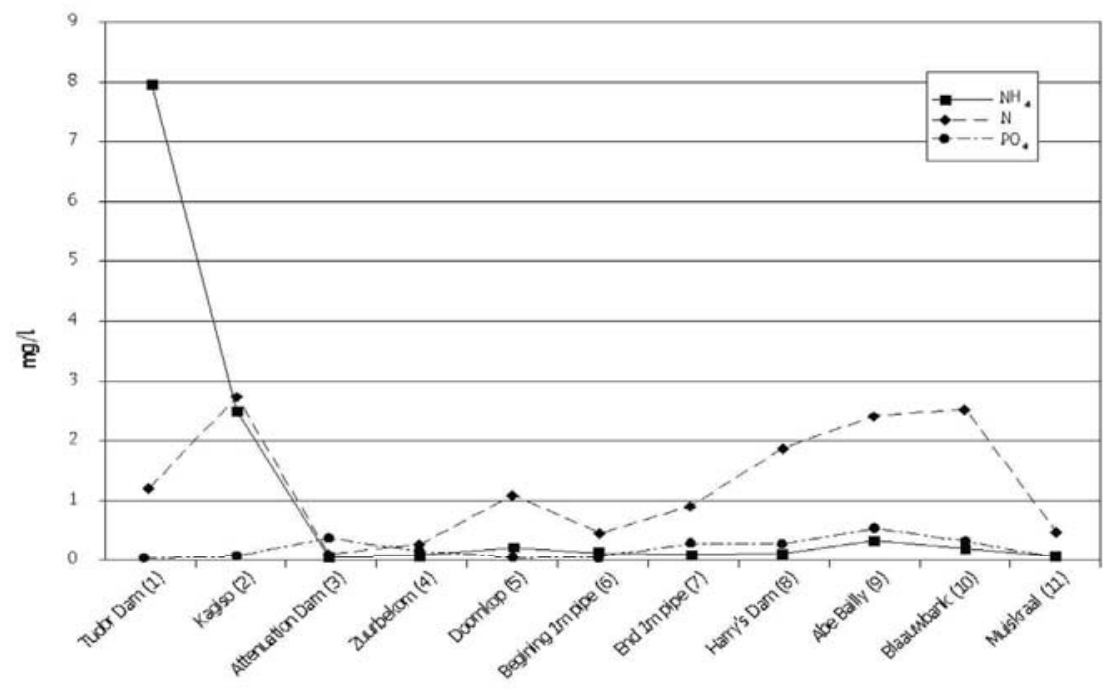

Figure 6

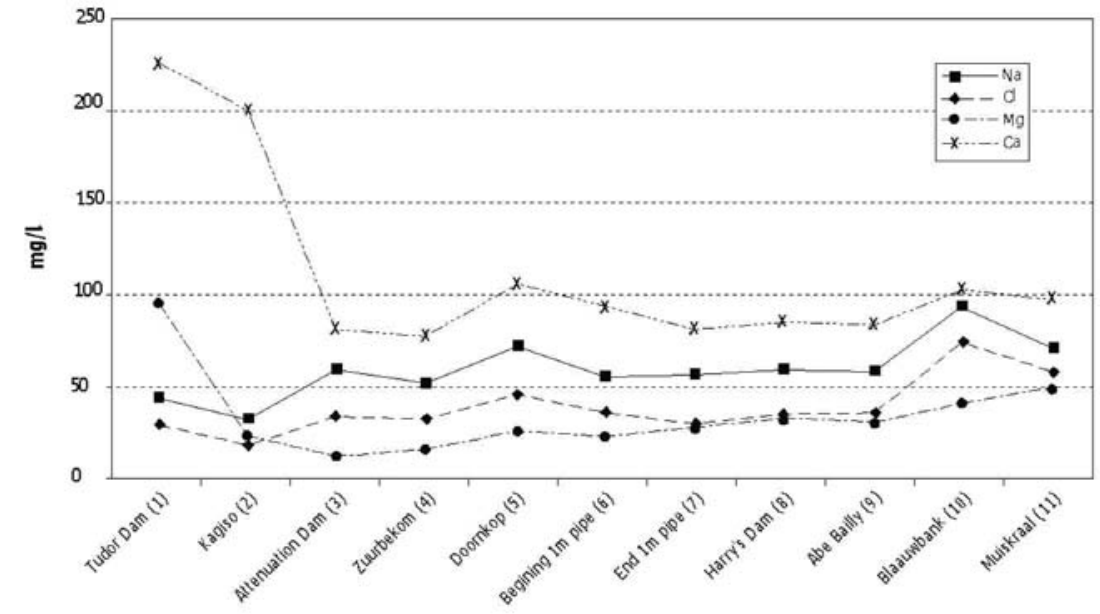

Figure 7

drop off with distance from the mining operations. However, the attenuation of waterborne radioactivity downstream is greater than could be explained by dilution by river water alone. Therefore it seems as if some of the heavy metals are accumulating in the sediments of the Mooi River system.

Winde (2000) analysed sediment samples from the Wonderfontein Spruit and calculated the average enrichment factor against the clay rock standard (Turekian \& Wedepohl, 1961) of heavy metals. These enrichment factors are shown in Figure 8. 


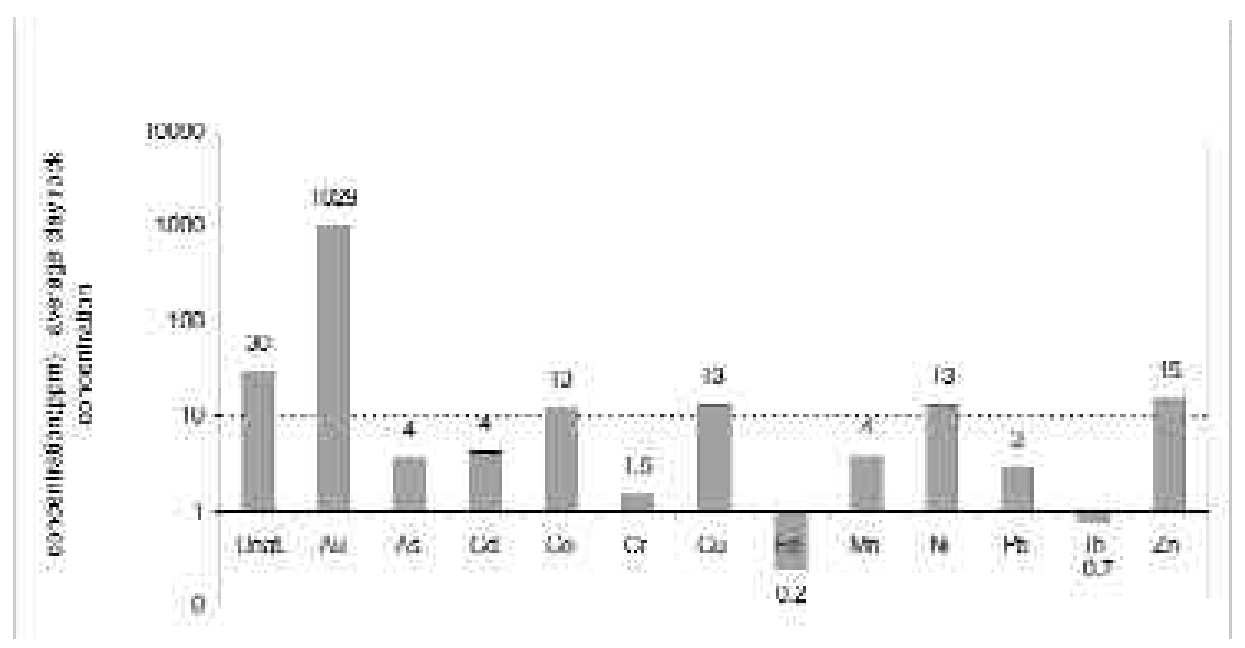

Figure 8. Average Enrichment of heavy metals in Wonderfontein Spruit sediments $(n=10)$.

The enrichment factors found by Winde (2000) confirm the view of Wade et.al. (2000) that the water column toxic metal concentrations might be maintained at a safe level for the preservation of health of the water users, while the sediments become enriched with respect to toxic metals.

The 30x enrichment factor of uranium is of particular concern due to the radiological effects as well as toxicity with regards to domestic consumption. Uranium is associated with the gold bearing ore that is found in the catchment. Before 1980, some uranium extraction plants were operational in the catchment, but due to a world-wide decline in the demand for uranium, the prices for uranium plummeted resulting in uranium extraction in South Africa drastically being reduced.

While uranium was extracted, contamination of the Wonderfontein Spruit occurred amongst others through effluent from extraction plants (point sources), but after extraction ceased, all uranium was left in the processed tailings and discharged to the slimes dams, resulting in diffuse contamination of streams and groundwater through erosion and seepage. This situation is still causing water and slimes, containing radio-nuclides and other heavy metals, to be introduced into the Mooi River via the Wonderfontein Spruit. Once in the stream channels, precipitation and settlement of most of the nuclides and metals take place. Elevated levels of nuclides are found in sediments of the Boskop Dam, and several "hot spots" have been identified in the Wonderfontein Spruit.

Coetzee (1998) did an airborne gamma ray scan of the upper Wonderfontein Spruit and concluded that the Wonderfontein Spruit is an important transport line of radioactive material from gold mine slimes dams. On the images, it can be clearly seen that radioactive material (nuclides) are seeping from decommissioned extraction plant sites as well as from slimes dams to the Wonderfontein Spruit, which transports it further down- 
stream. This solute transport mechanism is confirmed by concentrations of $0.02-$ $0.14 \mathrm{ppm} \mathrm{U}$ in the water of the Wonderfontein Spruit, while U concentrations in the stream sediments is in the range of 50-90ppm (Winde, 2000). Uranium concentrations of as high as $465 \mathrm{ppm}$ that occur in the sediments of some small dams and impoundments, indicate that such dams are acting as contaminant sinks. According to Wade et.al. (2000), six sites in the Wonderfontein Spruit (Tudor's Dam, Andre Coetzee's Dam, Sluice, Attenuation Dam, Donaldson Dam \& Harry's Dam) have U ${ }^{238}$ levels higher than allowed by the Nuclear Energy Act (1993), which is $0,2 \mathrm{~Bq} / \mathrm{kg}$ or equivalent to $16 \mathrm{mg} \cdot \mathrm{kg}^{-1} \mathrm{U}_{\text {nat }}$.

Although the radio-nuclides and other metals are mostly trapped in the sediments, it is possible that some of these contaminants can be mobilised under certain conditions like variations in $\mathrm{pH}$, redox conditions and also by resuspension of sediments during flood events. Since some of the mines are nearing decommissioning and closure, the rewatering of some of the dolomitic compartments is inevitable. This could lead to changes in the quality of water decanting into the Wonderfontein Spruit, which again can lead to the remobilization of nuclides and other metals in sediments. However, the exact nature and extent of the possible impact that rewatering of compartments could have on the water quality in the Wonderfontein Spruit, is still unknown.

\subsection{Longitudinal water quality - Mooi River}

Concentrations of some of the contaminants in the Mooi River are shown in Figures 9 to 11 .

The Klerkskraal Dam is not impacted upon by any mining activities. The only impacts on this dam are diffuse impacts as a result of farming activities (mainly grazing). Therefore the Klerkskraal Dam has been chosen as the reference point (control site) for the Mooi River catchment as a whole. The water quality in the Klerkskraal Dam is given in Table 1.

As expected, high TDS values are found in in the dolomitic water of the Bovenste eye. The high phosphates (Figure 10) are the result of difuse pollution from farming. The impact of the diamond diggings between Bovenste eye and the Boskop Dam on water quality, can be clearly seen in Figures 9 and 11. The rise in most contaminants between Potchefstroom Dam and Potchefstroom is the result of urban storm water runoff as well as a sizable industrial area (including a fertiliser factory). The impact of the Potchefstroom sewerage works can be observed mainly in the increase in phosphate levels at Kromdraai.

Table 1: Water quality in the Klerkskraal Dam

\begin{tabular}{|ccccccccccc|}
\hline $\begin{array}{c}\mathrm{U}^{238} \\
\mathrm{ug} / \mathrm{l}\end{array}$ & $\begin{array}{c}\mathrm{EC} \\
\mathrm{mS} / \mathrm{cm}\end{array}$ & $\begin{array}{c}\mathrm{TDS} \\
\mathrm{mg} / \mathrm{l}\end{array}$ & $\mathrm{pH}$ & $\begin{array}{c}\mathrm{Na} \\
\mathrm{mg} / \mathrm{l}\end{array}$ & $\begin{array}{c}\mathrm{F} \\
\mathrm{mg} / \mathrm{l}\end{array}$ & $\begin{array}{c}\mathrm{Cl} \\
\mathrm{mg} / \mathrm{l}\end{array}$ & $\begin{array}{c}\mathrm{SO}_{4} \\
\mathrm{mg} / \mathrm{l}\end{array}$ & $\begin{array}{c}\mathrm{NO}_{2} \\
\mathrm{mg} / \mathrm{l}\end{array}$ & $\begin{array}{c}\mathrm{NH}_{4} \\
\mathrm{mg} / \mathrm{l}\end{array}$ & $\begin{array}{c}\mathrm{PO}_{4} \\
\mathrm{mg} / \mathrm{l}\end{array}$ \\
\hline 0,25 & 41 & 347 & 8.3 & 5.6 & 0.151 & 5 & 10 & 0.043 & 0.026 & 0.022 \\
\hline
\end{tabular}

(Data from the Department of Water Affairs \& Forestry). 


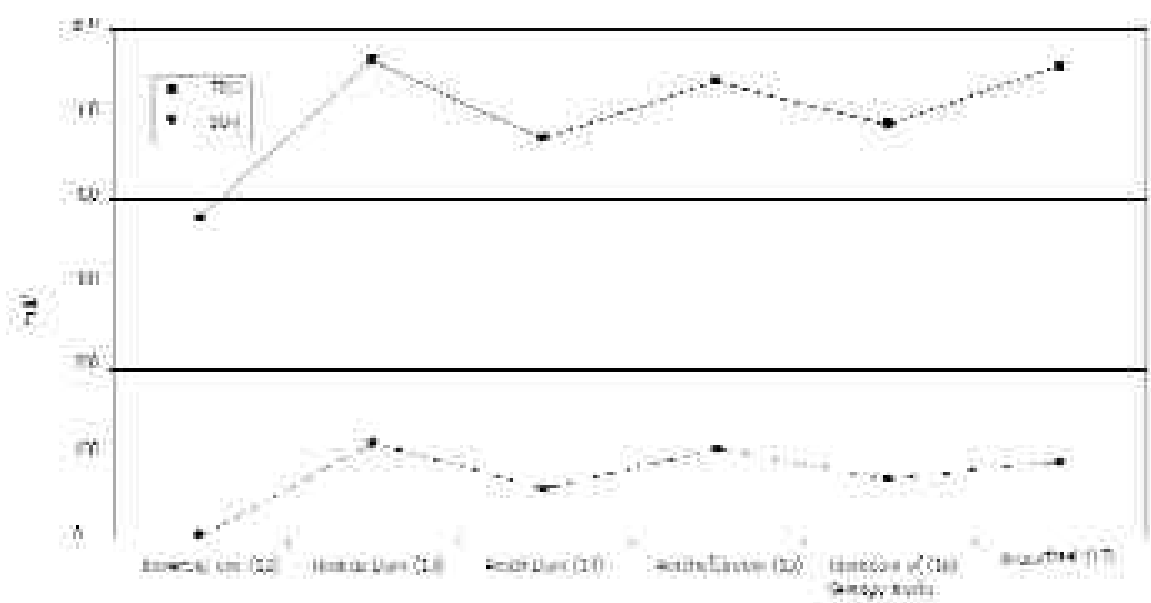

Figure 9

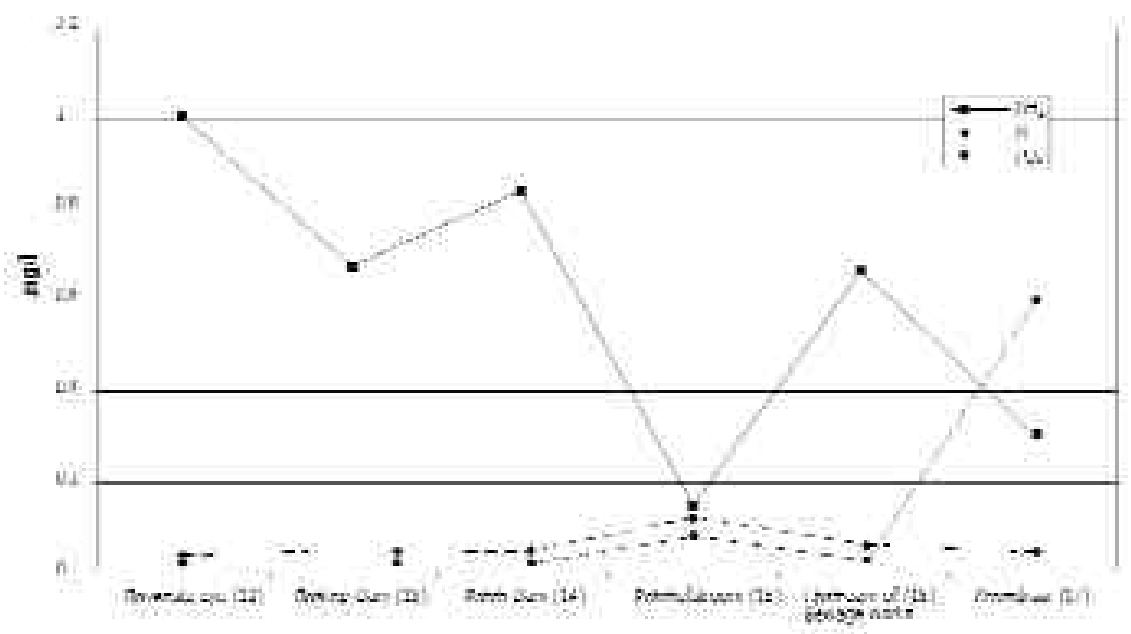

Figure 10

\subsection{Longitudinal water quality - Loop Spruit}

Concentrations of some of the contaminants in the Loop Spruit are shown in Figures 12 to 14 .

The water discharged by Kloof goldmine is of poor quality. The impact of Kukosi (an informal settlement) can be seen in the increase in the $\mathrm{N}$ concentration in Figure 13. Since there are two other goldmines discharging into the Loop Spruit between Kukosi and the Klipdrift Dam, it is expected that contaminant concentrations should increase instead of decrease. This anomaly is the result of dilution by a tributary of the Loop Spruit. 


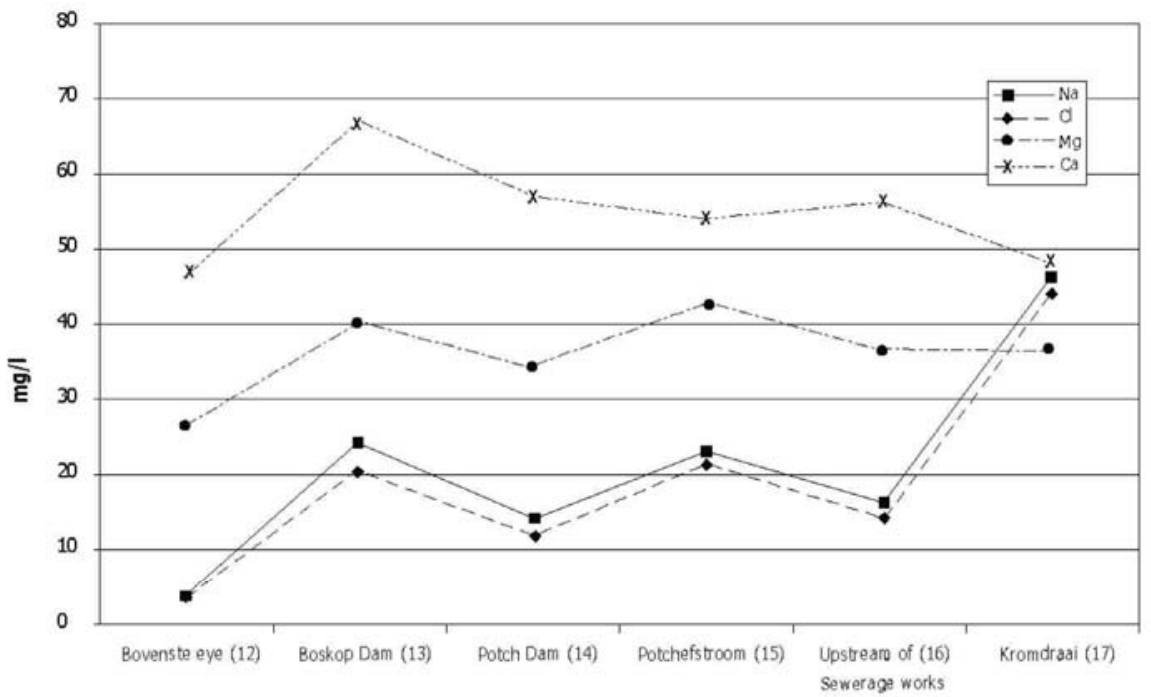

Figure 11

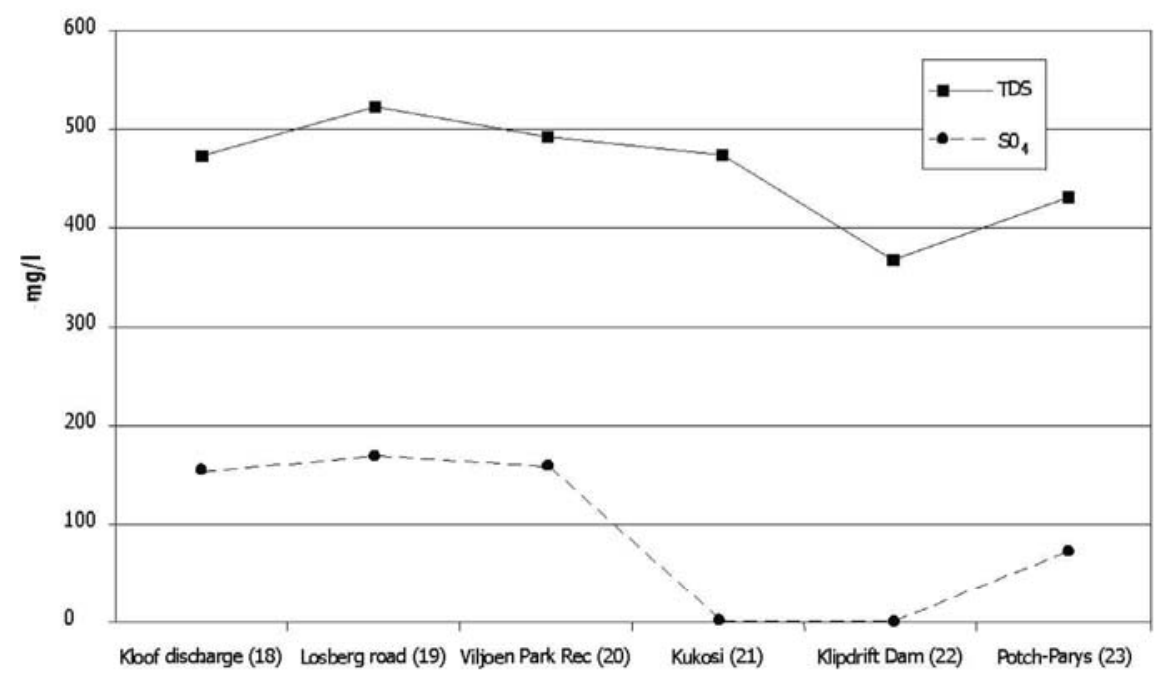

Figure 12

\section{Management Strategy}

Integrated Catchment Management is defined as a systems approach to the management of natural resources within the catchment area of a stream (DWAF, 1996). According to Görgens et.al. (1998), the ICM approach entails the division of a river into 


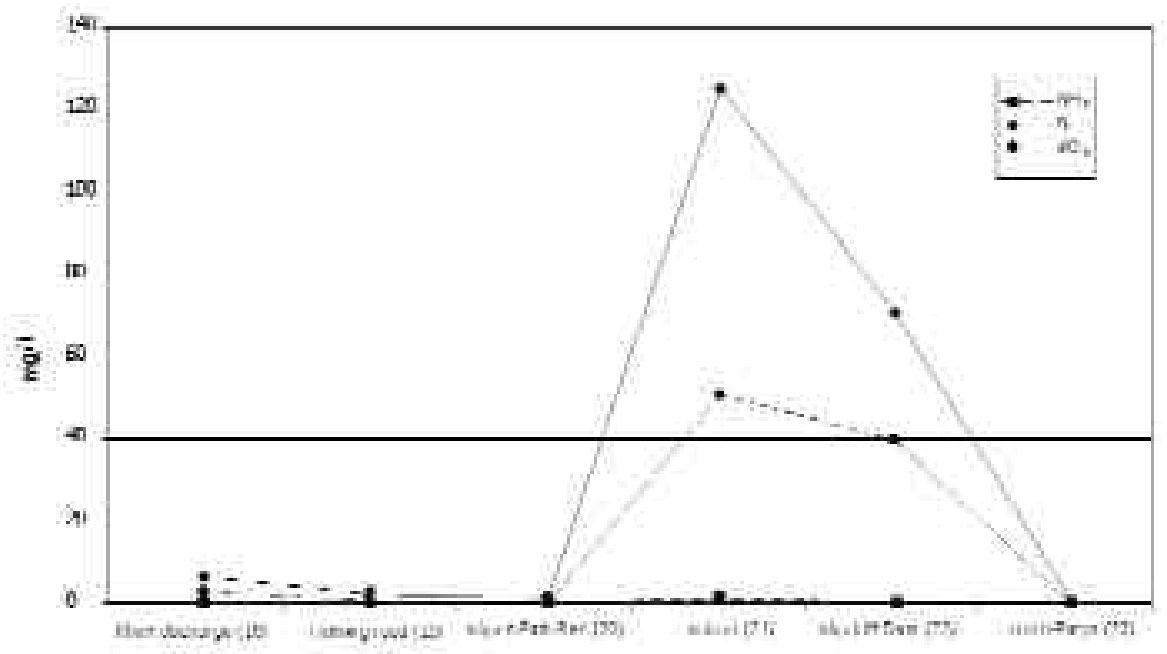

Figure 13

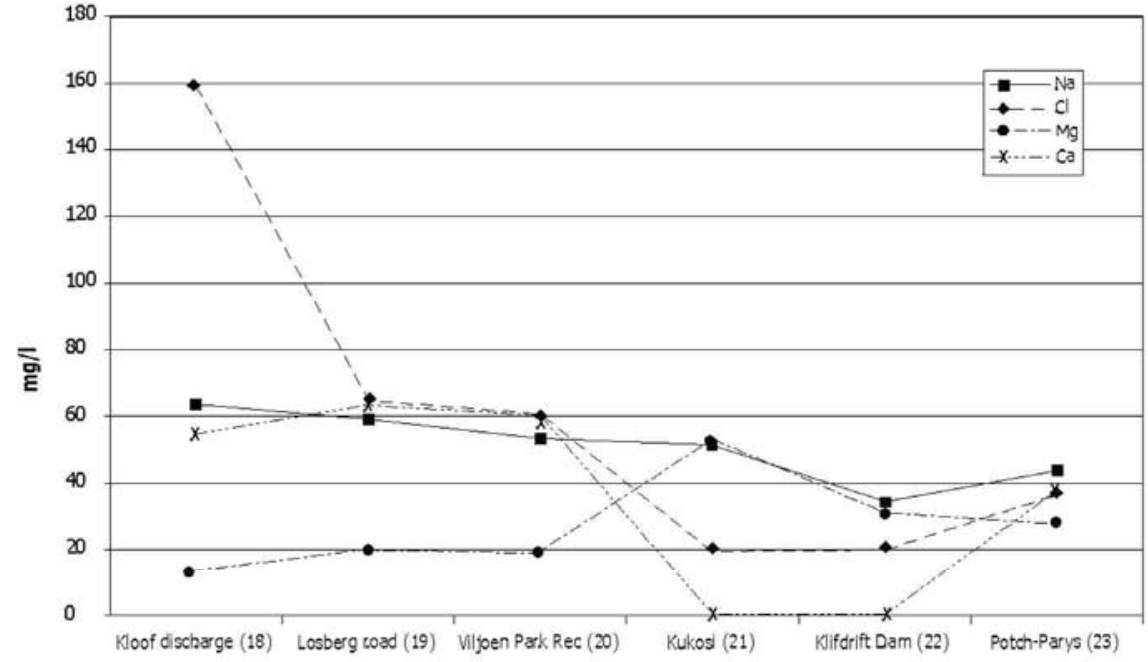

Figure 14

management units. These units can then be segmented together to create a comprehensive river basin management plan. In this way, a true systems approach will be achieved, where it is recognised that an impact in one location will be translated to all other parts of the system. 
The ISO14001 Environmental Management System approach is similar to the concept of Integrated Catchment Management (van Wyk, 2001). ISO14001 is widely accepted and applied throughout the world. In South Africa, some 130 companies have already been certified in terms of ISO14001 by the South African Bureau of Standards (van Rooy, 2001). It has been suggested that this system can serve as the basis for a catchment management system as well (van Niekerk et.al.,2000, van Wyk, 2001). The ISO14001 system has four main sections, namely Planning, Implementation and Operation, Checking and Corrective Action, and Management Review. The steps are iterative with continual improvement as aim.

The current approach of the South African Department of Water Affairs and Forestry to the development of a catchment management strategy is the following:

1. Situation analysis to determine the current status in the catchment

2. Identify required management tools

3. Set objectives regarding water quality and quantity

4. Develop management strategies

5. Develop the necessary infrastructure (Howard \& Heymans, 1999)

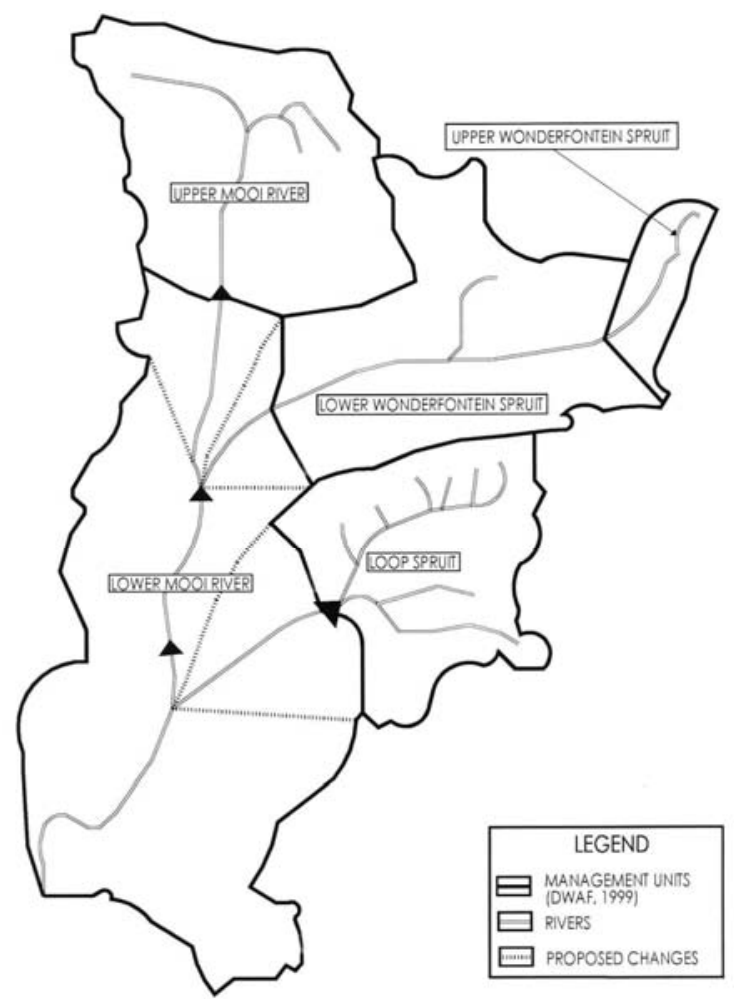

Figure 15 
When looking at the results of studies regarding the Mooi River System, it is clear that the design of an Integrated Catchment Management System is currently only in the Planning (situation analysis) stage. The situation analysis identified a number of gaps in the knowledge and understanding of the Mooi River system. For any management strategy to be successful, it must be based on a thorough understanding of the catchment dynamics. Therefore, all missing information must be gathered through investigations and research before a Integrated Catchment Management Plan could be formulated and implemented.

Howard \& Heymans (1999) suggested that the Mooi River Catchment be divided into the following management Units (Figure 15):

- The whole of the Upper Wonderfontein Spruit, to the intake of the $1 \mathrm{~m}$ pipe

- The Lower Wonderfontein Spruit, from the start of the $1 \mathrm{~m}$ pipe to Blaauwbank

- Loopspruit up to the Klipdrift Dam

- Upper Mooi River up to the Klerkskraal Dam

- Lower Mooi River, from the Klerkskraal Dam to the Vaal River, including the section from Blaauwbank as well as the Loop Spruit downstream of the Klipdrift Dam.

The authors, however, are of the opinion that the proposed management units should be adjusted to consist of sub-catchments with homogeneous characteristics. Three adjustments are proposed, namely:

i) Include the part of the catchment between the Klerkskraal Dam and the confluence with the Wonderfontein Spruit into the Upper Mooi River management unit - the only land-uses downstream of the Klerkskraal Dam are farming and diamond diggings. The impact on the water body should, except for turbidity, not differ substantially from the part of the catchment upstream of the Klerkskraal Dam;

ii) Extend the Lower Wonderfontein Spruit management unit up to the confluence with the Mooi River - the impacts in the Wonderfontein Spruit are likely to, in time, migrate towards the confluence with the Mooi River, where dilution will have an effect; and,

iii) extend the Loop Spruit management unit up to the Mooi River - the land-uses downstream of the Klipdrift Dam is similar to those found upstream, and the impacts of the upstream gold mines are likely to gradually migrate downstream towards the Mooi River.

For these management units, it is proposed that the "Reserve ${ }^{2 "}$ should be determined, all sources of pollution should be quantified and controlled, contaminated water should be treated, polluted areas should be rehabilitated, Receiving Water Body Standards (or

2 The "Reserve" is defined in the Water Act (1999) as the flow of water necessary to sustain the aqueous ecosystem as well as to fulfill basic human needs. All other water usages shall be subordinate to the "Reserve", 
Water Quality Objectives) should be set, the groundwater regime should be investigated, and "discharge charges" (the "polluter pays" principle) should be instigated.

According to Howard \& Heymans (1999), future management options for the catchment will be refined during the next phases of the catchment management strategy process once the exact nature and structure of the catchment management authority will be known. However, Maree (2001) estimates that the process of establishing the Catchment Management Agencies in South Africa could take a further 10 years. In the mean time, it is imperative that all water users and polluters should be represented in a "Water Forum" " for each sub-catchment to prevent further contamination and to mitigate current and future manifestations of pollution.

This management strategy is especially important in the light of the imminent rewatering of some of the dolomitic compartments. Indications are that, due to many years of pyrite oxidation, the water in the mine tunnels will initially have a low $\mathrm{pH}$. If these compartments start to decant into the Wonderfontein Spruit, the acid water could cause the trace metals to be mobilised, thereby creating a risk to downstream users. It is, however, also possible that the buffer capacity of the dolomites could neutralise the ground water. This aspect further illustrates the need for an integrated approach to catchment management based on thorough research.

\section{Conclusion and recommendations}

Integrated Catchment Management has been implemented across the world with varying degrees of success (Currie, 2001). South Africa is therefore in a position to implement insight and knowledge gained internationally within the local context. Considerations such as the need for communities to play a very active role in decision making needs to be included in the South African approach (DWAF, 1996). According to Görgens et.al. (1998), the improvement of collaboration and liaison between various government departments, as well as the implementation of complementary legislation pertaining to resource management is imperative for successful Integrated Catchment Management in South Africa.

With regards to the Mooi River, Currie (2001) developed an interactive, real-time environmental decision-making support system to facilitate the integrated catchment management approach using public domain software. This system utilises the Hydrological Simulation Programme - Fortran (HSPF), in conjunction with a data bank, an "Integrated Catchment Information System" as well as a graphic interface to simulate the complex hydrology and water chemistry of the Mooi River catchment. Although this system goes a long way in achieving Integrated Catchment Management for the Mooi River catchment, there remain some unanswered questions. Before any computer-based system will be able to support catchment managerial decisions, the following questions need to be answered:

3 The establishment of the "Water Forums" has already taken place. However, the representivity is still very poor and a huge effort weill be needed to improve the effectivity of these bodies. 
i) How can diffuse pollution, i.e. "who is to blame", be quantified? Diffuse pollution is mainly the result of farming activities. It is suggested that a self-governing approach, instead of policing, should be adapted to address this issue. Therefore a training programme for the farmers on the prevention of diffuse pollution by e.g. over-fertilisation should be considered.

ii) The question of continued seepage from disused slimes dams remains unanswered. Once the mines obtain a closure certificate, the problem will fall back to the government if timely provision is not made by way of dedicated trust funds to maintain tailings dams ad infinitum.

iii) Regarding any diversions of effluent to other catchments, the only viable catchment where effluent can be discharged to, is the Klip River catchment, west of Johannesburg. However, this river is already under very severe stress itself, e.g. uranium concentrations of 1,4 mg. $\mathrm{l}^{-1}$ in the running water (Nell, 2001:personal communication), and it is doubtful if it has the assimilative capacity to accept any further effluent. The principle of discharging waste from one catchment into another catchment also remains questionable.

iv) The assimilative capacity of the Mooi River as well as the Vaal River still needs to be determined. Only after the "Reserve" for each of the sub-catchments (or management units) of the Mooi River has been determined, the Instream Flow Requirements ${ }^{4}$ can be set. After that, the "polluter-pays"-principle could be followed to determine waste discharge charges.

v) Water demand management will only be possible after an Integrated Development Plan for the catchment, as a whole, has been compiled. The current practise is that land-use changes will only be allowed after obtaining a permit from the Department of Agriculture, Tourism \& Environment after an Environmental Impact Assessment has been submitted. However, these applications are viewed individually and the cumulative impacts are mostly not considered. Furthermore, if the raw water quality available to Potchefstroom deteriorates any more, the construction of a pipeline from the Klerkskraal Dam directly to Potchefstroom for the provision of domestic water should be considered. However, the high initial capital outlay and low operating costs of a pipeline should be weighed against the (probable) cheaper capital outlay but higher operational costs of sophisticated purification technologies.

vi) More research is needed before the interaction between the groundwater and the surface water regimes will be understood completely. The mines should exchange information and co-operate in a single research effort under supervision of an independent body.

vii)Due to the contamination of sediments in the Wonderfontein Spruit by radionuclides and other heavy metals, a clean-up strategy should be investigated immediately. Since Wade et.al. (2000) states that uranium is most likely to be solubilised by exposure of sediments to the atmosphere or by dredging operations, stream diversions should be considered when devising the clean-up strategy.

4 Instream Flow Requirements refers to the minimum flow, as well as flow variability necessary to sustain the aquatic ecology of a river. 
The interaction between the dolomitic underground compartments and the surface water regime in the Mooi River catchment is very complex and poorly understood. The huge impacts that mining and farming have on parts of this system, as well as the impacts of several towns and mushrooming informal settlements, complicates the situation even further. Up to now, attempts to manage this catchment have been uncoordinated and fragmented, resulting in the current manifestation of environmental problems caused by impacts that have been continuing for many years. An integrated approach is the only way in which this catchment can effectively be managed in order to provide a sustainable water supply for all organisms and people living within the catchment. For this, the Department of Water Affairs and Forestry needs to establish, as a matter of urgency, a Catchment Management Agency with the necessary skilled staff, funding, representivity, authority and commitment.

\section{References}

Coetzee, H. (1995). Radioactivity and the leakage of radioactive waste associated with Witwatersrand gold and uranium mining, International conference and workshop on Uranium Mining and Hydrogeology, Freiberg, Germany, 4-7 October, 1995.

Council for Geoscience of South Africa (Ed.) (1998). Mineral Resources of South Africa. Handbook 16. Pretoria, pp647-652

Currie, S.L. ( 2001). The implementation of an environmental desicion-making support system: the Mooi River catchment as a case study. (PhD disertation, Geography \& Environmental Studies, Potchefstroom University for Christian Higher Education).

Department of Water Affairs and Forestry. (1999). Report on the radiaoactivity monitor ing programme in the Mooi River (Wonderfontein Spruit) catchment. Institute for water quality studies, Report no. N/C200/00//RPQ/2399

Department of Water Affairs and Forestry. (1996). The philosophy and practices of inte grated catchment management: Implications for water resource management in South Africa. Water Research Commission Report TT81/96.

DWAF see Department of Water Affairs and Forestry.

Görgens, A., Pegram, G., Uys, M., Grobicki, A, Loots, L., Tanner, A. and Bengu, R. (1998). Guidelines for Catchment Management to achieve Integrated Water Resources Management in South Africa. Water Research Commission Report KV108/98.

Howard, M.R. and Heymans, S. (1999). Mooi River Catchment management study : Phase 1 situation analysis. DWAF : Pretoria.

Maree, D. (Deputy director, catchment management, DWAF). (2001). Personal communication.

Nell, B. (2001). Personal communication (Chief Chemist, Potchefstroom Town Council)

SACS (1980) see South African Committee for Stratigraphy.

South African Committee for Stratigraphy. (1980). Stratigraphy of South Africa (comp. L.E.Kent). Handbook of the Geological Survey of South Africa, 8. Government Printer, Pretoria. 
Turekian and Wedepohl (1961). Distribution of the elements in some major units of the earth's crust. Geological Society of America Bulletin, 72: 175-192.

Van Niekerk, L.J., Prinsloo, H.B. and Van der Walt, I.J. (2000). Technical audits. In: Sampson, I.R. (ed). The guide to environmental auditing on South Africa. Butterworths, Durban.

Van Rooy, J. (Head : Environmental assessment services : South African Bureau of Standards). 2001. Personal communication.

Van Wyk, J.J. (2001). Relations between integrated catchment management and ISO 14001. (PhD disertation, Geography \& Environmental Studies, Potchefstroom University for Christian Higher Education).

Wade, P.W., Woodborne, S., Morris, W.M., Vos, P. and Jarvis, N.V. (2000). Tier 1 Risk assessment of selected radionuclides in sediments of the Mooi River catchment. Water Research Commission project no K5/1095.

Winde, F. (2000). Fluviale Prozesse und Urantransport - Beispiele aus der Wismutregion Ostthüringens und Goldbergbaugebieten Südafrikas. Baumhauer H, Schütt B (Ed.): Geomorphologie und Umweltgeschichte. Jahrestagung des Arbeitskreises Geomorphologie in Trier (Germany), 4.-8.10.2000, Tagungsband, pp 41-42. 